\title{
THE EFFECT OF APPLYING GROUP INVESTIGATION METHOD ON STUDENTS' ACHIEVEMENT IN WRITING DESCRIPTIVE TEXT
}

\author{
Nurmahyuni Asrul ${ }^{1}$, Dwi Suci Amaniarsih², Juliana ${ }^{3}$ \\ nurmahyuniasrul@unprimdn.ac.id \\ amaniarsih86@gmail.com \\ juliana.ssmsi@gmail.com \\ Universitas Prima Indonesia ${ }^{1}$ \\ Universitas Potensi Utama ${ }^{2,3}$
}

\begin{abstract}
The purpose of this study was to determine whether the Group Investigation method had a significant effect on student achievement in writing descriptive texts. This research is quantitative by conducting an experimental design. The population used in this study was students of X SMK Shandy Putra 2 Medan. The sample of this study was randomly selected by taking 25 students for the experimental and control classes. Advertisement Pre-test Post-test is given to determine student scores. The score was calculated using the t-test formula. The results showed that the value of t-observation (2.44)> t-table (2.01) with df (48), meaning that the Group Investigation Method can improve student achievement in writing descriptive texts. So, the researcher concludes that there is a significant effect of the Group Investigation Method on student achievement in writing descriptive texts. And finally, the researcher gives suggestions to apply the method, especially the Group Investigation Method because it will have a significant influence on student achievement in writing descriptive texts.
\end{abstract}

Keywords: Writing, Descriptive Text, Group Investigation

\section{INTRODUCTION}

Everyone has varying abilities. This ability is built by several factors such as physical condition, intelligence, strength, ability, ability. Without these factors, a person cannot do well. Ability is the ability, ability, strength to complete tasks. Writing is an indirect communication tool with other people. Writing is an attempt to express everything that is in the concept of thought in the form of written or written language. Therefore, writing is an activity that requires the ability to express ideas, ideas, and writing in written language. But in reality, not everyone is capable of writing. Sometimes many people lose ideas in writing something. They are unable to develop a topic into a good writing.

Based on the researcher's observation in grade X Senior Vocational High School at SMK Shandy Putra 2 Medan that the ability of students' achievement in writing is still low and many students got their scores below the minimum standard value (KKM) which is 75 based on the writing descriptive text. In the first semester only $56 \%$ passed the minimum standar value, while the rest of that did not pass the minimum standart value. 
The preliminary observation data explains that many students felt difficult in writing descriptive test. There are several factors that cause students to fail in writing descriptive essays. The first is the inability of students to describe a certain object. Sometime they lost their ides when they describe something. The second is the students' lack of understanding in using the simple present tense, so that their writing has many grammatical errors. And the last is in the learning process, the teacher uses a conventional learning model, so that students in learning tend to only accept and are not active so that the learning objectives are not achieved.

Based on the explanation above, it is necessary to apply learning methods as a supportive solution so that students acquire abilities in writing skills. A good teaching and learning process is characterized by the interaction between students and teachers (Irwan \& Sani, 2015). The success or failure of the teaching and learning process is influenced by the teacher who acts as a facilitator, motivator, or inspiratory so that students can achieve good learning outcomes.

According to Sharan and Sharan in Maryam (1995) cluster Investigation methodology in concept of cooperative learning methodology may be a general schoolroom organization set up during which students add tiny cluster victimisation cooperative inquiry, give-and-take, and cooperative coming up with and project.

The reason for selecting the cluster Investigation is believed as a good method in increasing students writing action. By exploitation cluster Investigation methodology, students are ready to work along in an exceedingly cluster to investigate the subject of writing so as to seek out a lot of info from several sources and also the characteristics of descriptive texts. and also the scientist believes that this methodology will be the effective thanks to teach to boost the students' action as a result of cluster Investigation methodology could be a methodology that offer the liberty to seek out the data regarding one thing that need to analyze that the scientist decides to use this methodology.

According to Slavin in Maryam (2015:16) cluster Investigation is one in every of cooperative learning that is over having students add cluster however it additionally involves the employment of tasks whose completion needs the combined effort individual cluster members. cluster Investigation (GI) is devided the scholars into groups or little cluster, that the choose topics to analyze, gather info, prepare reports and present their furthermore.

In line with the previous resercher, Putri Delia (2018) in her research entitled Improving News Writing Skill by Using Cooperatif Type Group Investigation Strategy showed that there is an increasing achievement in news writing skills using strategy cooperatif type group investigation. This is evidenced from the average value of students in each cycle. The average value of 62.12 students in prasiklus then increased in the first cycle to 66.24 and the second cycle the average value of students increased to 87.00. Wasingah (2017) in her research about using Group Investigation in Islamic Studies found that the increase in learning outcomes since the 1st meeting and 2nd meeting of Cycle I to Cycle II shows evidence that the Group Investigation learning model can improve student learning outcomes.

Based on the background that has been expressed, the aim of this study is to work out the result of cluster Investigation (GI) on student writing learning outcomes 


\section{METHOD}

The method of the research is quantitative method by using Group Investigation Method. This study used an experimental design used pre-test and post-test. Technique in analyzing the data of the research used t- test. In quantitative research, data analysis techniques were used to answer the problem formulate on, then the data analysis use statistical methods.

In drawing the sample, the researcher used cluster random sampling. Two different classes were chosen, namely the experimental class and the control class. It represented the entire population which consisted of 50 students, 25 students for experimental group and 25 students for control group. They were X TKJ-1 as Experimental Group and X TB-1 as Control Group. Then, the sample of this research was selected randomly by taking 25 students for experimental and control classes. So, the total of samples was 50 students. Both classes were given a pre-test and post-test with the same instrument in the form of writing test. However, at the time of treatment, the experimental class was treated using the investigation group method while the control class was treated using the conventional method. Data analyzed in the form of test results from the control class and the experimental class using the t-test formula for free random samples so that they know the differences between control class and experimental class.

Table 1. Experimental Research Design

\begin{tabular}{|l|l|l|l|}
\hline Class & $\begin{array}{l}\text { Pre- } \\
\text { Test }\end{array}$ & $\begin{array}{c}\text { Treat } \\
\text { ment }\end{array}$ & Post-Test \\
\hline Experimental & $\mathrm{T}^{1}$ & $\mathrm{X}^{1}$ & $\mathrm{~T}^{2}$ \\
\hline Control & $\mathrm{T}^{1}$ & $\mathrm{X}^{2}$ & $\mathrm{~T}^{2}$ \\
\hline
\end{tabular}

\section{Note:}

T1 : Pre Test

T2 : Post-Test

X1 : Treatment by using Group Investigation Method

X2 : Treatment without Group Investigation Method

Before giving the treatments, a pre-test was administrated to the experimental group and control group. The pre-test was used to find out some sample and the mean score of each group. Having given the treatments, the post-test was given to each group. The items of the post-test were exactly the same as the one in the pre-test. It was intended to discover the mean score of the experimental group and the control group.

The researcher used t-test formula to know the differences between two classes. The formula is:

$$
\mathrm{t}=\frac{M_{X}-M_{Y}}{\sqrt{\left[\frac{\Sigma x^{2}+\Sigma y^{2}}{N_{x}+N_{y}-2}\right]\left[\frac{1}{N_{x}}+\frac{1}{N_{y}}\right]}}
$$


In which:

Mx : mean of the experimental group

My : mean of the control group

$\mathrm{X}$ : the deviation square of the experimental group

$\mathrm{Y}$ : the deviation square of the control group

$\mathrm{Nx}$ : the total number of samples of the

experimental group

NY : the total number of samples of the control group

\section{FINDING AND DISCUSSION}

The learning process using the Group Investigation Method begins with giving a Pretest, and then the students are divided into heterogeneous groups. Each group was given the task to identify the topic and then ended with Post-test. This is done to measure the mastery of students on descriptive essay material. The data acquisition from students' Pre-test and Post-test can be seen in the following table:

Table 2: Recapitulation of Pretest and Post-test in the Experiment class.

\begin{tabular}{|l|c|c|}
\hline \multicolumn{1}{|c|}{ Note } & Pre-test & Post-test \\
\hline The highest Score & 76 & 90 \\
\hline The lowest Score & 35 & 65 \\
\hline Total & 1546 & 2031 \\
\hline Average & 61,84 & 81,24 \\
\hline
\end{tabular}

Table 3: Recapitulation of Pretest and Post-test in the Control class.

\begin{tabular}{|l|c|c|}
\hline \multicolumn{1}{|c|}{ Note } & Pre-test & Post-test \\
\hline The highest Score & 76 & 90 \\
\hline The lowest Score & 35 & 65 \\
\hline Total & 1340 & 1660 \\
\hline Average & 53,6 & 66,4 \\
\hline
\end{tabular}

From each tables showed the scholars who were instructed by exploitation cluster investigation method got a far better result than those that who were instructed by exploitation conventional method.

The data analysis of the research was calculated using the soring criteria of descriptive texts in both experimental and control classes. The data was supposed to induce the many variations between instructed by applying cluster investigation method and instructed with conventional term in writing descriptive text.

Before conducting the research, the reseacher gave pre-test to both groups; experimental and control groups. The mean score of the pre-test in experimental was 61,84 and in the control group was 53,66.

The analyzing of data through pre-test and post-test in both groups, experimental group and control group were computed by using for t-test formula to prove the hyphotesis in this study. After applying group investigation method in experimental group and with conventional 
method in control group, the researcher gave post-test in order to obtain their scores. From the data obtained, it was discovered that the mean score of experimental group $(81,24)$ was higher than the control group $(66,40)$

The result of computing t-test shows that $\mathrm{t}_{\text {observed }}$ is higher than $\mathrm{t}$-table as follows:

$\mathrm{t}_{\text {observed }}>\mathrm{t}_{\text {table }}(\alpha=0.05 ; \mathrm{df}=48)$

$2,44>2,011(\alpha=0.05 ; \mathrm{df}=48)$

The result of calculation showed that the value of $t_{\text {observed }}$, that is 2,44 was higher than $t_{\text {table, }}$, that is 2,011 with $\mathrm{df} 48$ at level significance 0,05 . The researcher concluded that alternative hyphotesis $(\mathrm{Ha})$ is accepted and null hyphotesis $\left(\mathrm{H}_{0}\right)$ is rejected. It implies that " there is a vital impact of cluster investigation technique in writing descriptive text".

\section{CONCLUSION}

Based on the analysis findings, it absolutely was discovered that there's a major impact of applying cluster investigation technique on students' action in writing descriptive text. This is to say that students who were taught by applying group investigation method obtained better result than students who were taught by conventional method. ( $t_{\text {observed }}>t_{\text {table }} ; 2,44>2,011$.

Thus the use of group investigation is very helpful in the process of learning descriptive writing where students can better understand the material that has been taught by teacher in order to improve student learning outcomes so that they have good grades. At last, the researcher gives the suggestions for the English teacher to apply the method, especially Group Investigation Method because it will provide a significant effect on student achievement in writing descriptive texts.

\section{REFERENCES}

Agam, M, Ikhsan,K. 2013. Teaching Reading BY Combining Group Investigation and SQUIRT (Sustaines Quite Reading Time) Method At X Grade Senior High School. Journal of STKIP Sumatera Barat Vol 2.

Algarabel, S., and Carmen D. 2013. The Definition of Achievement and the Construction of Tests for Its Measurement: A Review of the Main Trend Section De Metodologia 22, 43-66.

Ary, D. Et. All. 2002. Introduction to Research in Education. United State : Wadsworth Group Harmer, J. 2004. How to Teach Writing. New York: Person Education Limited.

Khairunnisa, A. 2013. The Effect of Applying Example and Non Example Method on Students' Achievement in Writing Descriptive Text. Journal of English Language Teaching of State University of Medan.

Maryam, F. 2015. The Effect of Group Investigation Technique on The Students'

Achievement In Writing Descriptive Texts. Journal of English Language Teaching of

State University of Medan.

Pardiyono. 2007. Pasti Bisa! Teaching Genre-Based Writing. Yogyakarta : Andi Offset

Tangpermpoon, Thanatkun. 2008. Integrated Approaches to Improve Students Writing Skills for English Major Students. Retrieved June 10th2012 from ABC Journal Vol.28, No.2.

Yusuf, R. Malau. 2011. The Effect of Applying Clustering Technique on Students' Achievement in Writing Descriptive Paragraph. Medan: State University of Medan. 
Volume 9 Number 02 September 2021

ISSN 2338-3739 (Print)

ISSN 2614-8099 (online)

https://jurnal.unsur.ac.id/jeopallt

Authors: Nurmahyuni A., Dwi Suci A., and Juliana 